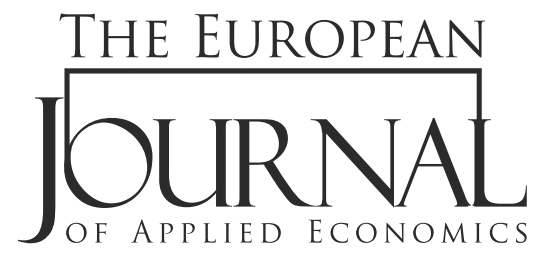

\title{
WHAT CAN WE EXPECT IN THE FUTURE OF ACADEMIC RESEARCH? MOST COMMON RESEARCH PROBLEMS ANALYSED IN THE TOP JOURNALS IN THE FIELD OF ENTREPRENEURSHIP
}

\author{
Irena Đalić ${ }^{*}$ \\ 1 Faculty of Transport and Traffic Engineering, University of East Sarajevo, \\ 52 Vojvode Misica Street, 74000 Doboj, Republic of Srpska, B\&H
}

\begin{abstract}
:
In the modern era of academic research, it is extremely difficult to define an entirely or largely unexplored research problem. Every researcher is faced with this question in their research. It takes a lot of work and effort to primarily find a topic that is relevant and that will be attractive for study and research. The focus of this paper is research problems related to the field of entrepreneurship. This paper deals with trending research problems over the course of the last five years in the field of entrepreneurship. The survey was conducted with the aim of identifying the least explored areas of entrepreneurship in order to predict future research topics. The methods used to achieve this scientific goal include: description, classification and explanation. By analyzing the sample of 393 papers from the five most cited journals in the field of entrepreneurship, the author came to the conclusion that in the past five years the majority of papers dealt primarily with the topic of innovation and advanced technology, and hardly touched upon the topic of women's entrepreneurship. This paper should help future researchers to select the topics or fields of research in the domain of entrepreneurship.
\end{abstract}

Article info:

Received: April 02, 2019

Correction: May 08, 2019

Accepted: May 15, 2019
Keywords:

entrepreneurship, journals, indexed, citations 


\section{INTRODUCTION}

What initiated the publication of research results in scientific journals is the need of scientists and researchers to communicate with each other and gain an insight into current studies. The age of scientific journals dates from1665, when the French Journal des sçavans and the English journal Philosophical Transactions of the Royal Society began to periodically publish the results of scientific studies (Kronick, 1976). After the appearance of these journals, there was an increase in the number of journals in all areas of scientific studies. A significant number of journals are specialized in one particular area of scientific research, although there are newspapers which publish articles in various fields of research. Papers published in journals deal with the latest studies in a particular scientific field. Papers published in scientific journals are mainly intended for immediate scientific community and may be incomprehensible to those who are not sufficiently familiar with the particular area of research that the journal deals with.

There are several types of papers published in scientific journals, although the exact terminology and definitions vary depending on the scientific field they focus on, as well as from the scientific journals themselves. The papers published in journals according to the Regulations on publishing scientific publications in the Republic of Srpska (RS Official Gazette, 2017, no. 77/17), can be categorized as: original scientific papers, review papers, short or preliminary communications, critical reviews, informative annexes, books, instruments, computer software, cases, scientific event reports, and the like. The format of scientific papers can vary greatly from journal to journal. Despite that, the rules of writing journal papers are mainly determined by IMRAD methodology, recommended by the International Committee of Medical Journal Editors (ICMJE). There is a profusion of articles on the subject of what IMRAD methodology is and how to use it (Radek, 2016; Vuckovic, 2014; Papakostidis \& Giannoudis, 2018; Malicki, 2016; Nair \& Nair, 2014; Bertin \& Atanassova, 2014; Krausman et al. 2016).

This paper focused on the analyses of journals in the field of entrepreneurship that currently rank among top five with regard to the number of citations. A total amount of 393 papers from 5 journals (Research Policy, Entrepreneurship Theory and Practice, Journal of Business Venturing, Small Business Economics, Journal of Product Innovation Management) published from 2013 until the beginning of 2018 were analyzed, providing that the papers from the beginning of 2018 were taken into account as well.

According to the conducted research it will be possible to determine which topic is most frequently and most commonly explored, and which one is investigated (explored) to an insufficient/inadequate degree. These results could show what will happen in the current research trends in the field of entrepreneurship in the upcoming years. The main goal of this paper is to draw attention to the unexplored areas in the field of entrepreneurship and provide guidance for future researchers regarding the problems that need to be solved.

In the first part of the paper, the author will review the relevant literature to confirm the relevance of our research. The second part relates to the indexing of journals and citation database. In this section, our goal is to explain what general indexing and citation is and how citation database is formed. The results of the research are presented in the third part of the paper. In this section, the author will describe the problems faced during the research, along with research findings. In the end, the author summarizes these findings and provides the list of relevant literature used in this research. 


\section{LITERATURE REVIEW}

There are numerous studies dealing with the analysis of journals in all research fields. This is not an unfamiliar topic. In this way, the question of which topics are extensively and which ones poorly explored in a given field of study is answered. Such a study is the research by Ritzberger (2008) in which he analyzed and ranked the various journals in the field of economics. There are many authors who have tried to classify and explain the ranking of journals in the field of economy (Kalaitzidakis, Mamuneas \& Stengos, 2003; Lubrano, Bauwens, Kirman \& Protopopescu, 2003; Kodrzycki \& Yu, 2006; Mingers \& Harzing, 2007; Bornmann, Butz \& Wohlrab, 2018). The fact that many authors have dealt with the explanation of different methods of ranking journals in the field of economy proves that this job is not easy (Liner \& Amin, 2004; Koczy \& Strobel, 2007; Wohlrab, 2016; Subochev, Aleskerov \& Pislyakov, 2018).

We have already noted that the focus of this paper is to analyze research problems in the field of entrepreneurship. Several authors have dealt with this theme so far (Rey-Martí, Ribeiro-Soriano \& Palacios-Marqués, 2016; Alvarez-Garcia, Maldonado-Erazo, del Río \& Sarang-Lalangue, 2018; LópezFernández Serrano Bedia \& Pérez Pérez, 2016; Xu, Chen, Fung \& Chan, 2018; Ferreira, Reis \& Miranda, 2015; McDonald, Gan, Fraser, Oke \& Anderson, 2015). In our paper, the author focused on the problems that are most studied and on the ones that are least studied in the field of entrepreneurship. In this way, the author wants to give a scientific contribution and advise future scientists what to study in the near future; and that is what this paper aims to achieve. This is supported by the fact that, through this research related to the top five journals in the field of entrepreneurship, which are the highest ranked in the last five years (2013-2018), not a single paper that deals with the analysis of journals in the field of entrepreneurship turned up. The part of the paper associated with the literature review will include three areas that are most and two areas that are least explored.

The vast majority of the authors who have fallen within the scope of the research have studied the character of innovation and advanced technologies and their influence on the growth and development of enterprises and the economy (Werfel \& Jaffe, 2013; Hashi \& Stojčić, 2013; Thomä \& Bizer, 2013; Musteen \& Ahsan, 2013; Dachs \& Peters, 2014; Hung \& Tu, 2014; Dai, Maksimov, Gilbert \& Fernhaber, 2014; Sahut \& Peris-Ortiz, 2014; Audretsch, Coad \& Segarra, 2014; Slater, Mohr \& Sengupta 2014; Venturini, 2015; Block, Fisch, Hahn \& Sandner, 2015; Sarooghi, Libaers \& Burkemper, 2015; Parrilli \& Heras, 2016; Visnjic, Wiengarten \& Neely, 2016; Walsh, Lee \& Nagaoka, 2016; Dorner, Fryges \& Schopen, 2017; Nambisan, 2017; Belderbos, Jacob \& Lokshin, 2018; De Massis, Audretsch, Uhlaner \& Kammerlander, 2018). All these authors have dealt with the character of innovation and advanced technologies and their influence on the growth and development of enterprises and the economy. This research has shown that innovation is crucial for the development of enterprises, especially for the development of enterprises which were engaged in some form of advanced technologies ever since their establishment. In order for such companies to survive in the turbulent business environment, they have to turn to innovation and continuous improvement of their operations (Colombel, Krafft \& Vivarelli, 2016).

In addition, there are authors who have studied theoretical entrepreneurship and the importance of introducing the subject of entrepreneurship at universities in order to educate young people in this area (McCloskey, 2013; Leyden, 2014; Zhang \& Cueto, 2017; Abreu \& Grinevich, 2013; Freitas, Marques \& e Silva, 2013; Jung, 2014; Mowery \& Ziedonis, 2015; Muscio, Quaglione \& Ramaciotti, 2016; Walter, Parboteeah \& Walter, 2013; McCaffrey, 2014; Walter \& Block, 2016; Braunerhjelm, Ding \& Thulin, 2018; Guerrero, Urbano, Fayolle, Klofsten \& Mian, 2016). 
The next field considering the number of published papers is the field that relates to knowledge, or the sources of knowledge (Huber, 2013; Autant-Bernard, Fadairo \& Massard, 2013; Olmos-Peñuela, 2014; Agarwal \& Shah, 2014; Batabyal \& Beladi, 2015; Roper, Love \& Bonner, 2017; Marvel, 2013; Musteen, Datta \& Butts, 2014; Frederiksen, Wennberg \& Balachandra, 2016; Zahra, 2015). These authors strived to highlight the importance of knowledge both in the development of enterprises and starting a business. In order for entrepreneurs to realize their ideas, they must first gain certain knowledge and skills.

One of the least explored areas is family business. Several authors have dealt with this kind of entrepreneurship. (Jaskiewicz, Block, Combs \& Miller, 2017; Parker, 2016; Le Breton-Miller \& Miller, 2015; Memili, Fang, Chrisman \& De Massis, 2015; Cruz, Larraza-Kintana, Garcés-Galdeano \& Berrone, 2014; Schmid, Achleitner, Ampenberger \& Kaserer, 2014; Wilson, Wright \& Scholes, 2013; Brannon, Wiklund \& Haynie, 2013).

The lowest number of papers in the survey (a total of 393 papers), with only two exploring this field being recorded in the five journals, refers to female entrepreneurship (Hunt, Garant, Herman \& Munroe, 2013; Eddleston, Ladge, Mitteness \& Balachandra, 2016).

It is impossible to cover the entire sample of 393 papers that were involved in the research. Therefore, in this section, only a few papers relating to certain fields of the research are presented. The classification of papers in various areas, as well as the fact that the topics discussed in these journals are now trending, will be discussed in the part of this paper related to the research results.

\section{INDEXING OF JOURNALS AND CITATION DATABASE}

Until the end of the nineties of the 20th century, the collection of references and data on citations was conducted by hand and came down to text reading and data input in the appropriate fields in the database. Today this work is automated (Bergmark, 2000; Besagni, 2004; Cronin \& Sugimoto, 2015). Computer programs are being used that, based on optical character recognition of texts in digitized print or electronic versions of scientific papers, identify relevant bibliometric data (title, author's name, affiliation author, abstract, keywords, references, title of the parent publication, and when it comes to newspapers - their volume, number, pagination, place of publication, publisher standard numbers ISBN, ISSN, dOI, etc., information about the funder of research), and then, using complex algorithms, these computer programs analyze and classify data in the fields within the database (JACS, 2010). It is very important that authors and journals strictly adhere to standards when quoting references. Thus processed data serve as the basis for bibliometric analysis. Citation analysis was first conducted by Garfield (2006; 1965). According to him, citation analysis is examination of incidence, patterns and graphs of citations in articles and books. The number of citations a certain paper has shown how many times individual scientists cited a paper in their papers, thus showing its use value which has its own qualities. This dimension of quality is usually described by expressions such as echo, the significance, the importance of scientific paper. These terms, however, say nothing about the character of the paper, the reasons why the paper is important, useful, or has an echo. According to Plomp (1994), the indicator of scientific success of a particular author's paper is that paper being cited at least 25 times. So during the 1960s bibliographic database were first formed because of the need to allow users to easily monitor, search and access the most relevant literature. An indexed bibliographic database monitors and handles a large number of carefully selected publications, most of which consist of papers from scientific journals. 
A separate entity within the bibliographic databases makes reference database. Citing is a common practice in scientific communication, so authors end their papers with a list of references. Citation databases are secondary sources of scientific and technical literature which, with bibliographic description of the document (paper, book, etc.), consists of a list of references that the author/authors of the document referenced. The primary task of citation indexes is to serve as a source of relevant scientific literature, because the system of inclusion of journals and/or documents and publications has an inbuilt mechanism of selectivity. The role of the citation indexes as a tool of bibliometrics and scientometrics is primarily to assess the quality of scientific productivity (of articles, journals, etc.) in the creation of a scientific policy, and to easily track the most reviewed and most important publications in the areas of science (Meho \& Yang, 2007). The most famous three citation databases are Web of Science, Scopus and Google Scholar:

1. Bibliographic database Current Contents (CC) and citation databases Science Citation Index (SCI), Social Sciences Citation Index (SSCI) and Arts and Humanities Citation Index (AHCI) are the most selective worldwide databases. They were made by the Institute for Scientific Information (ISI) from Philadelphia by the year 2004 (that is why they are called "ISI" databases), after which they were acquired by Thomson Corporation (Thomson Reuters). As of 1997, these citation databases merged into a single database, Web of Science (WoS). Web of Science is the oldest citation database (includes paper s from 1900 to the present), which includes the world's scientific literature which is a subject to very strict selection and quality control. This service contains multiple databases available on the Internet: Science Citation Index Expanded, Social Sciences Citation Index, Arts and Humanities Citation Index, Conference Proceedings Citation Index - Science Conference Proceedings Citation Index-Social Science \& Humanities. Since 2005, the Web of Science has been merged with the Book Citation Index (includes monographs by major publishers), and since 2012 with the Data Citation Index (primary data) (more about this in: Falagas, Pitsouni, Malietzis \& Pappas 2008; Erfanmanesh, Didegah \& Omidvar, 2017).

2. The index database Scopus was launched by the multinational publishing company Elsevier. This service includes approximately 22,000 journals, mostly from the field of medicine, natural and social sciences. It is possible to find citations in the literature published after 1996. A feature of this database is that it covers Biomedical Science much better than all the others, but it is not entirely systematic and consistent (more on this in: Bosman, Mourik, Rasch, Sieverts \& Verhoeff, 2006; de Moya-Anegón, 2007; Khiste \& Paithankar, 2017).

3. Google Scholar is an electronic resources browser, which can search the entire academic literature available on the Internet, without any selection. Consequently, many versions of the same reference may be found on different sites. However, older literature is poorly represented. Furthermore, Google Scholar does not provide a list of publishers whose data it collects, the list of journals, information about the time period or scientific disciplines it covers (more on this in: Jacso, 2005; Bar-Ilan, 2008).

The same journal can be represented in a number of relevant databases. The analysis of citations in ISI citation databases obtains numerical indicators. The most popular among them is called the Impact Factor (IF) (Jemec, 2001). The IF is a measure that includes the annual average number of citations of recently published papers from that journal (Garfield, 1999). It is often used as an expression of the relative importance of the journal in a given field. Journals with higher IF are usually considered more important than those with lower value factors. The current year journals' IF is calculated by dividing the number of citations received in the current year for papers published in the previous two years by the number of papers published in the same two-year period. The impact factor is calculated by the following formula (Sombatsompop, Markpin \& Premkamolnetr, 2004; de \& Rijcke Rushforth, 2015): 


$$
I F_{y}=\frac{\text { Citations }_{y-1}+\text { Citations }_{y-2}}{\text { Publications }_{y-1}+\text { Publications }_{y-2}}, y=\text { the current year }
$$

When using the number of citations as an indicator of the paper quality, there are several reasons why it is necessary to be cautious. It cannot be said that no one reads the papers that are not quoted or that these papers have no scientific value, although one's scientific contribution is often reflected in high citation rate (Oosthuizen \& Fenton, 2014). In addition, the very act of citation does not imply recognition in a positive way, but it may also be motivated by the need for correction, criticism or denial of ideas and papers of others (Verma, 2015). Although ISI emphasizes the multidisciplinary and international character of its databases, and the quality of the journal that it deals with as well, there was, throughout its history, a lot of criticism when it comes to the representation of national journals and certain disciplines (Elliott, 2014). The reason for the criticism is its focus on newspapers in English and on developed countries at the expense of small countries, developing countries and non-English-speaking countries (Callaway, 2016).

\section{RESULTS AND LIMITATIONS OF THE RESEARCH}

During the research, which lasted from early April until the end of May 2018, the author was able to form a random sample of 393 papers from the field of entrepreneurship. The total number of paper published in these five journals is much larger, but the author, in this period of research and, in view of the limitations, managed to collect 393 papers. The author analyzed the papers from the five journals that are currently considered as most cited in the field of entrepreneurship. During the research, the author used the method of description, classification and explanation, owing to which some useful results were obtained which will be discussed in this section. Obtained data and research results will be shown in the tables for the sake of clarification. When sorting and analyzing data, statistical methods to calculate the mean, median and mode motion were used, along with the methods whose purpose was to find the maximum and minimum values.

\section{LImitations of the research}

The author has decided to choose this topic because it is trending (popular, recent, current) and so as to, for the sake of future studies, give a clearer picture of what topics have and haven't already been explored. In this way, both us and future researchers who deal with entrepreneurship problems will be able to select the topics that will allow them to actually contribute to science.

In addition to being faced with minor technical problems during the research, the author also experienced a bigger problem. Namely, since the author is not subscribed to any journal indexed database, it was very difficult to obtain relevant journals and papers. Despite the promises, the Ministry of Science and Technology did not provide funds that would allow the scientific community of the Republic of Srpska to subscribe to any of the afore-stated databases. This method of support would greatly help researchers to come up with relevant literature which is extremely useful in research of any field of science as it would, first and foremost, shorten the time necessary to conduct studies.

After a long period of researching and collecting the relevant literature from available sources, the author was able to form a sample of 393 papers and thus, more or less, successfully overcome this problem. 


\section{Results of the research}

The author has already mentioned at the beginning that the subject of analysis were papers from the five journals that have been among the top quoted ones in the last five years. They are:

1. Research Policy,

2. Entrepreneurship Theory and Practice,

3. Journal of Business Venturing,

4. Small Business Economics,

5. Journal of Product Innovation Management.

In Table 1 the author will show the participation of the journal according to the number of papers in the total sample.

Table 1 - Journals' participation in the sample.

\begin{tabular}{cccc}
\hline No. & Name & No. of papers & Share \\
\hline 1. & Research Policy & 123 & $31.30 \%$ \\
\hline $2 . t$ & Entrepreneurship Theory and Practice & 91 & $23.15 \%$ \\
\hline 3. & Journal of Business Venturing & 76 & $19.34 \%$ \\
\hline 4. & Small Business Economics & 49 & $12.47 \%$ \\
\hline 5 & Journal of Product Innovation Management & 54 & $13.74 \%$ \\
\hline TOTAL & & 393 & $100.00 \%$ \\
\hline
\end{tabular}

Source: The author

Table 1 shows that the majority of papers is collected from the journal Research Policy (IF: 4.661) which also ranks first as the most cited journal in the field of entrepreneurship (123 papers or 31.30\% of the total sample). The second positioned source of papers is the journal Entrepreneurship Theory and Practice (IF: 4.916), which is in the second place regarding the number of citations with 91 papers or $23.15 \%$. The next one, in terms of the number of papers in the sample, is the third-ranked journal - Journal of Business Venturing (IF: 6.000) with 76 papers or 19.34\%. The fourth place in the sample is taken by the fifth-ranked Journal of Product Innovation Management (IF: 4.305) with 54 papers or 13.74\%. Whereas the fifth place in the sample holds the journal Small Business Economics (IF: 2.852) with 49 papers or 12:47\%. According to these results, we can see that the journal which ranks first in the number of citations was the most accessible to the author, because she was able to collect 123 paper samples from it. The least accessible to the author was the journal Small Business Economics from which the author obtained 49 papers. 
The author classified all 393 papers according to the studied areas and divided them into 8 groups:

1. Sources of knowledge for entrepreneurs and small and medium enterprises,

2. Research management,

3. Theoretical and educational contribution to entrepreneurship,

4. Family business,

5. Financing SMEs,

6. Innovation and advanced technology,

7. Women's entrepreneurship, and

8. State's support in the development of entrepreneurship and the SME sector.

The main goal of this research is to try and obtain the answer to the question: what is the most commonly studied section in the field of entrepreneurship, that is, what section is the most commonly studied and which one the least explored in the last five years? By obtaining an answer to this question we can make a prediction on what section of entrepreneurship will be the most researched in the future. Table 2 shows the sample papers' share in the sections listed below.

Table 2 - The sample papers' share in the research sections.

\begin{tabular}{clcc}
\hline No. & Section in the field of entrepreneurship & No. of papers & Share \\
\hline 1 & Innovation and advanced technology & 114 & $29.01 \%$ \\
\hline 2 & $\begin{array}{l}\text { Theoretical and educational contribution to entre- } \\
\text { preneurship }\end{array}$ & 104 & $26.46 \%$ \\
\hline 3 & Sources of knowledge & 56 & $14.25 \%$ \\
\hline 4 & $\begin{array}{l}\text { State's support in the development of entrepreneur- } \\
\text { ship and the SME sector }\end{array}$ & 52 & $13.23 \%$ \\
\hline 5 & Financing SMEs & 35 & $8.91 \%$ \\
\hline 7 & Research management & 18 & $4.58 \%$ \\
\hline 8 & Family business & 12 & $3.05 \%$ \\
\hline TOTAL & & 2 & $0.51 \%$ \\
\hline
\end{tabular}

Source: The author

Table 2 shows the period from 2013 to 2018, provided that the author took papers from the beginning of 2018 into account papers which were published by the time this study was conducted.

Table 2 clearly shows that the majority of papers are the ones published in the field of innovation and advanced technology, a total of 114 or $29.01 \%$ of the sample. The next sector, considering the number of papers, is the sector that relates to the theoretical and educational contribution to entrepreneurship. Most of these papers discuss the importance of introducing entrepreneurship as a subject at universities and schools. There were 104 papers dealing with this theme or $26.46 \%$ of the total sample. According to the number of published papers, the next one is the sector of sources of knowledge with 56 papers or $14,25 \%$ of the total sample. In this sector, the authors mostly dealt with the importance of knowledge acquisition and skills in the field of entrepreneurship and how to provide this knowledge. A large number of authors dealt with state policies concerning the support in the development of entrepreneurship and the SME sector. These authors pointed out the importance and contribution 
of government support in the development of entrepreneurship. Yet the state is the one that needs to deal with all issues related to the development of its economy. The total sample has 52 papers related to this field or $13.23 \%$. Then there are papers related to the field of SMEs funding. The authors have studied different sources of financing small businesses, especially businesses that deal with advanced technologies, and risky jobs. These are mostly newer forms of financing such as angel investors, venture capital funds, mezzanine financing, crowdfunding and others. A number of 35 papers covers this field or $8.91 \%$. The last three places are held by the management studies sector with 18 papers or $4.58 \%$, the family business sector with 12 papers or $3.5 \%$ and the women's entrepreneurship sector with only two papers in the total sample or $0.51 \%$.

The author will specify in Table 3 how great the sample journals' participation in the different sectors of entrepreneurship is.

\begin{tabular}{|c|c|c|c|c|c|c|}
\hline $\begin{array}{l}\text { Journal } \\
\text { Research } \\
\text { sector }\end{array}$ & $\begin{array}{l}\text { Research } \\
\text { Policy }\end{array}$ & $\begin{array}{l}\text { Entrepre- } \\
\text { neurship } \\
\text { Theory and } \\
\text { Practice }\end{array}$ & $\begin{array}{l}\text { Journal of } \\
\text { Business } \\
\text { Venturing }\end{array}$ & $\begin{array}{l}\text { Small Busi- } \\
\text { ness Eco- } \\
\text { nomics }\end{array}$ & $\begin{array}{l}\text { Journal of } \\
\text { Product } \\
\text { Innovation } \\
\text { Management }\end{array}$ & $\sum$ \\
\hline \multirow{2}{*}{$\begin{array}{l}\text { Innovation and } \\
\text { advanced tech- } \\
\text { nology }\end{array}$} & 55 & 20 & 7 & 22 & 10 & 114 \\
\hline & $48.25 \%$ & $17.54 \%$ & $6.14 \%$ & $19.30 \%$ & $8.77 \%$ & $100 \%$ \\
\hline \multirow{2}{*}{$\begin{array}{l}\text { Theoretical and } \\
\text { educational con- } \\
\text { tribution to en- } \\
\text { trepreneurship }\end{array}$} & 20 & 28 & 39 & 11 & 6 & 104 \\
\hline & $19.23 \%$ & $26.92 \%$ & $37.50 \%$ & $10.58 \%$ & $5.77 \%$ & $100 \%$ \\
\hline \multirow{2}{*}{$\begin{array}{l}\text { Sources of knowl- } \\
\text { edge }\end{array}$} & 5 & 13 & 21 & 14 & 3 & 56 \\
\hline & $8.93 \%$ & $23.21 \%$ & $37.50 \%$ & $25.00 \%$ & $5.36 \%$ & $100 \%$ \\
\hline \multirow{3}{*}{$\begin{array}{l}\text { State's support in } \\
\text { the development } \\
\text { of entrepreneur- } \\
\text { ship and the SME } \\
\text { sector }\end{array}$} & 23 & 18 & 1 & - & 10 & 52 \\
\hline & $44.23 \%$ & $34.62 \%$ & $1.92 \%$ & - & $19.23 \%$ & $100 \%$ \\
\hline & 8 & 4 & 5 & - & 18 & 35 \\
\hline \multicolumn{7}{|l|}{ Financing SMEs } \\
\hline & $22.86 \%$ & $11.43 \%$ & $14.28 \%$ & - & $51.43 \%$ & $100 \%$ \\
\hline \multirow{2}{*}{$\begin{array}{l}\text { Research manage- } \\
\text { ment }\end{array}$} & 10 & - & 3 & 5 & - & 18 \\
\hline & $55.55 \%$ & - & $16.67 \%$ & $27.78 \%$ & - & $100 \%$ \\
\hline & 1 & 7 & - & 2 & 2 & 12 \\
\hline \multicolumn{7}{|l|}{ Family business } \\
\hline & $8.33 \%$ & $58.33 \%$ & - & $16.67 \%$ & $16.67 \%$ & $100 \%$ \\
\hline \multirow{2}{*}{$\begin{array}{l}\text { Women's entre- } \\
\text { preneurship }\end{array}$} & 1 & 1 & - & - & - & 2 \\
\hline & $50.00 \%$ & $50.00 \%$ & - & - & - & $100 \%$ \\
\hline$\sum$ & 123 & 91 & 76 & 54 & 49 & 93 \\
\hline
\end{tabular}


Table 3 shows how great the participation of a particular journal is within each sector of entrepreneurship, of course, all in the context of the sample of 393 papers. In the sector of innovation and advanced technology, the dominant journal is Research Policy with $48.25 \%$ of the articles, while the lowest participation has the Journal of Business Venturing with only 6.14\%. As for the sector of theoretical and educational contributions to entrepreneurship, the largest share of $37.50 \%$ has the Journal of Business Venturing, while the lowest participation in the same field of entrepreneurship has the Journal of Product Innovation Management with 5.77\%. Within the sector relating to the sources of knowledge, the largest share has the Journal of Business Venturing with 37.50\%, while the lowest share has the Journal of Product Innovation Management with 5.36\% of papers in this research field. In the sector of state support, the journal with the biggest share is Research Policy with $44.23 \%$ of the articles, while the journal Small Business Economics has no papers in this field. In the sector of financing SMEs, the largest share has the Journal of Product Innovation Management with 54.43\% of the articles, while the journal Small Business Economics has no involvement in this field. In the sector of research management, the largest share has the journal Research Policy with $55.55 \%$ of papers and journals, while the journals Entrepreneurship Theory and Practice and the Journal of Product Innovation Management have not published any papers in this field of entrepreneurship. In the sector of family business, the largest share has the journal Entrepreneurship Theory and Practice with $58.33 \%$ of the articles, while the lowest share has the Journal of Business Venturing that has not published a paper in this scientific field. According to this research, women's entrepreneurship is the least studied in the field of entrepreneurship. There are only two papers, one from the journal Research Policy and the other one from the journal Entrepreneurship Theory and Practice.

According to this research we can see clearly that the most frequently studied sector in the context of entrepreneurship is the one that refers to innovation and advanced technology. In the total sample of 393 papers from the five currently most cited journals in the field of entrepreneurship, there is 114 or $29.01 \%$ of papers dealing with this topic. Therefore, this sector is quite explored when it comes to entrepreneurship, but considering the fact that this field is subject to constant change, it will be vastly researched in the future and many papers concerning this topic will be published.

On the other hand, there are only two papers covering the topic of women's entrepreneurship in our sample. Therefore, this area is still on the sidelines of entrepreneurship research. Women's entrepreneurship as a research topic is quite attractive and there should be a lot of research done considering that the role of women both in entrepreneurship and in the economy in general is always a popular topic. The position of women in the economy is an issue that is still insufficiently explored, and which should be studied furthermore since authors constantly strive to promote and maintain gender equality in all fields of life, including social and economic, and also in the field of entrepreneurship. Furthermore, according to the results of research ( $8.91 \%$ of the sample), it can be concluded that the papers in the field of funding risky entrepreneurial ventures from alternative or new sources of financing are insufficiently covered topics that deserve more research attention. 


\section{CONCLUSIONS}

After the survey, the author formed a sample of 393 papers from five currently most cited journals. The collected papers were published from 2013 until the beginning of 2018. Due to limited access to relevant databases of indexed journals, our sample contains 393 papers that the author has been able to collect during the survey. The papers were selected randomly, so that the author could not influence the results of the research.

According to the research results, it is concluded that the journal Research Policy, which also ranks first in the citation, was the most approachable. That is, the author managed to collect 123 papers from this journal which makes up $31.30 \%$ of the sample. The majority of papers that the author collected from this journal were about innovation and advanced technologies (55 papers), and the least presented papers dealt with the topics of family business and women's entrepreneurship ( 1 paper per each field) while the ratio, in these fields, is the same in the total sample. Most of the papers relate to the field of innovation and advanced technology and the field of women's entrepreneurship has the fewest papers.

The worst approach was in the case of the Journal of Product Innovation Management, from which the author was able to get 49 papers, whereas only 5 more paper (54) was the author able to take over from the journal Small Business Economics.

According to the results of the survey, the most frequently studied entrepreneurship area is the one that refers to innovation and advanced technologies. The majority of the papers concerned this topic (114 of 393). Therefore, this area occupies $29.01 \%$ of the total sample. The author believe that this field will continue to be attractive because there are always interesting topics for researchers in this field of entrepreneurship.

The aim of this research was to find an area that is not explored sufficiently enough in the context of entrepreneurship. The author believes that this goal was achieved.

According to the survey the author came to the conclusion that female entrepreneurship and financing of high-risk entrepreneurial ventures are the topics that are insufficiently explored in entrepreneurship in general. In the total sample of 393 papers there are only two papers dealing with female entrepreneurship. They make up only $0.51 \%$ of the sample. Female entrepreneurship is a very popular topic these days when women are more and more encouraged to get involved in all economic trends and in entrepreneurship as well. The author thinks that there is a lot that needs to be done to empower women's entrepreneurship, particularly in transition economies where the role of women in the economy is still marginalized.

The author leaves future researchers with so many open and unanswered questions, such as: the role of women in transition economies, ways to overcome the traditional problems in these economies when it comes to women, the future and the perspective of women's entrepreneurship, ways to acquire certain knowledge and skills to start a business and many other questions. The answers to these questions should be applied not only in theory but in practice too. Such researches should help women to dare to start a business, because there are plenty of ideas but there is not enough courage to realize them. 


\section{REFERENCES}

Abreu, M., \& Grinevich, V. (2013). The nature of academic entrepreneurship in the UK: Widening the focus on entrepreneurial activities. Research Policy, 42(2), 408-422.

Agarwal, R., \& Shah, S. K. (2014). Knowledge sources of entrepreneurship: Firm formation by academic, user and employee innovators. Research Policy, 43(7), 1109-1133.

Audretsch, D. B., Coad, A., \& Segarra, A. (2014). Firm growth and innovation. Small business economics, 43(4), 743-749.

Autant-Bernard, C., Fadairo, M., \& Massard, N. (2013). Knowledge diffusion and innovation policies within the European regions: Challenges based on recent empirical evidence. Research Policy, 42(1), 196-210.

Bar-Ilan, J. (2008). Which h-index? -A comparison of WoS, Scopus and Google Scholar. Scientometrics, 74(2), 257-271.

Batabyal, A. A., \& Beladi, H. (2015). Knowledge goods, ordinary goods, and the effects of trade between leading and lagging regions. Research Policy, 44(8), 1537-1542.

Belderbos, R., Jacob, J., \& Lokshin, B. (2018). Corporate venture capital (CVC) investments and technological performance: Geographic diversity and the interplay with technology alliances. Journal of Business Venturing, 33(1), 20-34.

Bergmark, D. (2000). Automatic extraction of reference linking information from onlinedocuments. Cornell University.

Bertin, M., \& Atanassova, I. (2014). A study of lexical distribution in citation contexts through the IMRaD standard. PloS Negl. Trop. Dis, 1(200,920), 83-402.

Besagni, D. (2004, January). Citation recognition for scientific publications in digital libraries. In null (p. 244). IEEE.

Block, J. H., Fisch, C. O., Hahn, A., \& Sandner, P. G. (2015). Why do SMEs file trademarks? Insights from firms in innovative industries. Research Policy, 44(10), 1915-1930.

Bornmann, L., Butz, A., \& Wohlrabe, K. (2018). What are the top five journals in economics? A new meta-ranking. Applied Economics, 50(6), 659-675.

Bosman, J., Mourik, I. V., Rasch, M., Sieverts, E., \& Verhoeff, H. (2006). Scopus reviewed and compared: The coverage and functionality of the citation database Scopus, including comparisons with Web of Science and Google Scholar.

Brannon, D. L., Wiklund, J., \& Haynie, J. M. (2013). The varying effects of family relationships in entrepreneurial teams. Entrepreneurship Theory and Practice, 37(1), 107-132.

Braunerhjelm, P., Ding, D., \& Thulin, P. (2018). The knowledge spillover theory of intrapreneurship. Small business economics, 51(1), 1-30.

Callaway, E. (2016). Publishing elite turns against impact factor. Nature, 535(7611), 210-211.

Cronin, B., \& Sugimoto, C. R. (Eds.). (2015). Scholarly metrics under the microscope: from citation analysis to academic auditing (pp. 933-940). Association for Information Science and Technology by Information Today, Incorporated.

Cruz, C., Larraza-Kintana, M., Garcés-Galdeano, L., \& Berrone, P. (2014). Are family firms really more socially responsible?. Entrepreneurship Theory and Practice, 38(6), 1295-1316.

Dai, L., Maksimov, V., Gilbert, B. A., \& Fernhaber, S. A. (2014). Entrepreneurial orientation and international scope: The differential roles of innovativeness, proactiveness, and risk-taking. Journal of Business Venturing, 29(4), 511-524.

De Massis, A., Audretsch, D., Uhlaner, L., \& Kammerlander, N. (2018). Innovation with Limited Resources: Management Lessons from the G erman M ittelstand. Journal of Product Innovation Management, 35(1), 125-146. 
de Moya-Anegón, F., Chinchilla-Rodríguez, Z., Vargas-Quesada, B., Corera-Álvarez, E., Muñoz-Fernández, F. J., González-Molina, A., \& Herrero-Solana, V. (2007). Coverage analysis of Scopus: A journal metric approach. Scientometrics, 73(1), 53-78.

Dorner, M., Fryges, H., \& Schopen, K. (2017). Wages in high-tech start-ups-Do academic spin-offs pay a wage premium?. Research policy, 46(1), 1-18.

Eddleston, K. A., Ladge, J. J., Mitteness, C., \& Balachandra, L. (2016). Do you see what I see? Signaling effects of gender and firm characteristics on financing entrepreneurial ventures. Entrepreneurship Theory and Practice, 40(3), 489-514.

Elliott, D. B. (2014). The impact factor: a useful indicator of journal quality or fatally flawed?. Ophthalmic and Physiological Optics, 34(1), 4-7.

Erfanmanesh, M. A., Didegah, F., \& Omidvar, S. (2017). Research productivity and impact of Library and Information Science in the Web of Science. Malaysian Journal of Library \& Information Science, 15(3), 85-95.

Falagas, M. E., Pitsouni, E. I., Malietzis, G. A., \& Pappas, G. (2008). Comparison of PubMed, Scopus, web of science, and Google scholar: strengths and weaknesses. The FASEB journal, 22(2), 338-342.

Ferreira, M. P., Reis, N. R., \& Miranda, R. (2015). Thirty years of entrepreneurship research published in top journals: analysis of citations, co-citations and themes. Journal of Global Entrepreneurship Research, 5(1), 17.

Frederiksen, L., Wennberg, K., \& Balachandran, C. (2016). Mobility and Entrepreneurship: Evaluating the Scope of Knowledge-Based Theories of Entrepreneurship. Entrepreneurship Theory and Practice, 40(2), 359-380.

Freitas, I. M. B., Marques, R. A., \& e Silva, E. M. D. P. (2013). University-industry collaboration and innovation in emergent and mature industries in new industrialized countries. Research Policy, 42(2), 443-453.

Garfield, E. (1965, December). Can citation indexing be automated. In Statistical association methods for mechanized documentation, symposium proceedings (Vol. 269, pp. 189-192). Washington, DC: National Bureau of Standards, Miscellaneous Publication 269.

Garfield, E. (1999). Journal impact factor: a brief review. Canadian Medical Association Journal, 161(8), 979-980.

Garfield, E. (2006). Citation indexes for science. A new dimension in documentation through association of ideas. International journal of epidemiology, 35(5), 1123-1127.

Guerrero, M., Urbano, D., Fayolle, A., Klofsten, M., \& Mian, S. (2016). Entrepreneurial universities: emerging models in the new social and economic landscape. Small Business Economics, 47(3), 551-563.

Hashi, I., \& Stojčić, N. (2013). The impact of innovation activities on firm performance using a multi-stage model: Evidence from the Community Innovation Survey 4. Research Policy, 42(2), 353-366.

Huber, F. (2013). Knowledge-sourcing of R\&D workers in different job positions: Contextualising external personal knowledge networks. Research Policy, 42(1), 167-179.

Hung, S. C., \& Tu, M. F. (2014). Is small actually big? The chaos of technological change. Research Policy, 43(7), $1227-1238$

Hunt, J., Garant, J. P., Herman, H., \& Munroe, D. J. (2013). Why are women underrepresented amongst patentees?. Research Policy, 42(4), 831-843.

Jacso, P. (2005). As we may search-comparison of major features of the Web of Science, Scopus, and Google Scholar citation-based and citation-enhanced databases. Current science, 89(9), 1537-1547.

Jacso, P. (2010). The impact of Eugene Garfield through the prism of Web of Science.

Jaskiewicz, P., Block, J. H., Combs, J. G., \& Miller, D. (2017). The effects of founder and family ownership on hired CEOs' incentives and firm performance. Entrepreneurship Theory and Practice, 41(1), 73-103.

Jemec, G. B. (2001). Impact factor to assess academic output. The Lancet, 358(9290), 1373.

Jung, H. J. (2014). The impacts of science and technology policy interventions on university research: Evidence from the US National Nanotechnology Initiative. Research policy, 43(1), 74-91.

Kalaitzidakis, P., Mamuneas, T. P., \& Stengos, T. (2003). Rankings of academic journals and institutions in economics. Journal of the european economic association, 1(6), 1346-1366. 
Khiste, G. P., \& Paithankar, R. R. (2017). Analysis of Bibliometric term in Scopus. International Journal of Library Science and Information Management (IJLSIM), 3(3), 81-88.

Kóczy, L. A., \& Strobel, M. (2007). The ranking of economics journals by a tournament method. Mimeographed, University of Maastricht.

Kodrzycki, Y. K., \& Yu, P. (2006). New approaches to ranking economics journals. The BE Journal of Economic Analysis \& Policy, 5(1).

Krausman, P. R., Cox, A. S., \& Knipps, A. C. (2016). Abstract abstracts and other abstractions. The Journal of Wildlife Management, 80(6), 955-956.

Kronick, D. A. (1976). A history of scientific and technical periodicals: the origins and development of the scientific and technological press, 1665-1790.

Le Breton-Miller, I., \& Miller, D. (2015). Article Commentary: The Arts and Family Business: Linking Family Business Resources and Performance to Industry Characteristics. Entrepreneurship Theory and Practice, 39(6), 1349-1370.

Leyden, D. P., Link, A. N., \& Siegel, D. S. (2014). A theoretical analysis of the role of social networks in entrepreneurship. Research Policy, 43(7), 1157-1163.

Liner, G. H., \& Amin, M. (2004). Methods of ranking economics journals. Atlantic Economic Journal, 32(2), 140-149.

López-Fernández, M. C., Serrano-Bedia, A. M., \& Pérez-Pérez, M. (2016). Entrepreneurship and family firm research: A bibliometric analysis of an emerging field. Journal of Small Business Management, 54(2), 622-639.

Lubrano, M., Bauwens, L., Kirman, A., \& Protopopescu, C. (2003). Ranking economics departments in Europe: a statistical approach. Journal of the European Economic Association, 1(6), 1367-1401.

Malički, M. (2016). POUZDANOST ZNANSTVENIH PUBLIKACIJA U BIOMEDICINI (Doctoral dissertation, University of Split. School of Medicine.).

Marvel, M. R. (2013). Human Capital and Search-Based Discovery: A Study of High-Tech Entrepreneurship. Entrepreneurship theory and practice, 37(2), 403-419.

McCaffrey, M. (2014). On the theory of entrepreneurial incentives and alertness. Entrepreneurship Theory and Practice, 38(4), 891-911.

McCloskey, D. N. (2013). Tunzelmann, Schumpeter, and the hockey stick. Research Policy, 42(10), 1706-1715.

McDonald, S., Gan, B. C., Fraser, S. S., Oke, A., \& Anderson, A. R. (2015). A review of research methods in entrepreneurship 1985-2013. International Journal of Entrepreneurial Behavior \& Research, 21(3), 291-315.

Meho, L. I., \& Yang, K. (2007). Impact of data sources on citation counts and rankings of LIS faculty: Web of Science versus Scopus and Google Scholar. Journal of the american society for information science and technology, 58(13), 2105-2125.

Memili, E., Fang, H., Chrisman, J. J., \& De Massis, A. (2015). The impact of small-and medium-sized family firms on economic growth. Small Business Economics, 45(4), 771-785.

Mingers, J., \& Harzing, A. W. (2007). Ranking journals in business and management: a statistical analysis of the Harzing data set. European Journal of Information Systems, 16(4), 303-316.

Mowery, D. C., \& Ziedonis, A. A. (2015). Markets versus spillovers in outflows of university research. Research Policy, 44(1), 50-66.

Muscio, A., Quaglione, D., \& Ramaciotti, L. (2016). The effects of university rules on spinoff creation: The case of academia in Italy. Research Policy, 45(7), 1386-1396.

Musteen, M., \& Ahsan, M. (2013). Beyond cost: the role of intellectual capital in offshoring and innovation in young firms. Entrepreneurship Theory and Practice, 37(2), 421-434.

Musteen, M., Datta, D. K., \& Butts, M. M. (2014). Do International Networks and Foreign Market Knowledge Facilitate SME Internationalization? Evidence From the C zech R epublic. Entrepreneurship theory and practice, 38(4), 749-774. 
Nair, P. R., \& Nair, V. D. (2014). Organization of a Research Paper: The IMRAD Format. In Scientific Writing and Communication in Agriculture and Natural Resources (pp. 13-25). Springer, Cham.

Nambisan, S. (2017). Digital entrepreneurship: Toward a digital technology perspective of entrepreneurship. Entrepreneurship Theory and Practice, 41(6), 1029-1055.

Olmos-Peñuela, J., Castro-Martínez, E., \& D’Este, P. (2014). Knowledge transfer activities in social sciences and humanities: Explaining the interactions of research groups with non-academic agents. Research Policy, 43(4), 696-706.

Oosthuizen, J. C., \& Fenton, J. E. (2014). Alternatives to the impact factor. the surgeon, 12(5), 239-243.

Papakostidis, C., \& Giannoudis, P. V. (2018). Impact Factor and Altmetrics: What Is the Future?. In Medical Writing and Research Methodology for the Orthopaedic Surgeon (pp. 71-79). Springer, Cham.

Parker, S. C. (2016). Family firms and the "willing successor" problem. Entrepreneurship Theory and Practice, 40(6), 1241-1259.

Parrilli, M. D., \& Heras, H. A. (2016). STI and DUI innovation modes: Scientific-technological and context-specific nuances. Research Policy, 45(4), 747-756.

Plomp, R. (1994). The highly cited papers of professors as an indicator of a research group's scientific performance. Scientometrics, 29(3), 377-393.

Pravilnik o publikovanju naučnih publikacija u Republici Srpskoj. (2017). Službeni glasnik RS, br. 77/17. 14-23

Radek, I. (2016). I. MEĐUNARODNA KONFERENCIJA UDRUGE NASTAVNIKA JEZIKA STRUKE NA VISOKOŠKOLSKIM USTANOVAMA" OD TEORIJE DO PRAKSE U JEZIKU STRUKE”. Strani jezici: časopis za primijenjenu lingvistiku, 44(1), 70-73.

Rey-Martí, A., Ribeiro-Soriano, D., \& Palacios-Marqués, D. (2016). A bibliometric analysis of social entrepreneurship. Journal of Business Research, 69(5), 1651-1655.

Ritzberger, K. (2008). A ranking of journals in economics and related fields. German Economic Review, 9(4), $402-430$

Roper, S., Love, J. H., \& Bonner, K. (2017). Firms' knowledge search and local knowledge externalities in innovation performance. Research Policy, 46(1), 43-56.

Rushforth, A., \& de Rijcke, S. (2015). Accounting for impact? The journal impact factor and the making of biomedical research in the Netherlands. Minerva, 53(2), 117-139.

Sahut, J. M., \& Peris-Ortiz, M. (2014). Small business, innovation, and entrepreneurship. Small Business Economics, 42(4), 663-668.

Sarooghi, H., Libaers, D., \& Burkemper, A. (2015). Examining the relationship between creativity and innovation: A meta-analysis of organizational, cultural, and environmental factors. Journal of business venturing, 30(5), 714-731.

Schmid, T., Achleitner, A. K., Ampenberger, M., \& Kaserer, C. (2014). Family firms and R\&D

behavior-New evidence from a large-scale survey. Research Policy, 43(1), 233-244.

Slater, S. F., Mohr, J. J., \& Sengupta, S. (2014). Radical product innovation capability: Literature review, synthesis, and illustrative research propositions. Journal of Product Innovation Management, 31(3), 552-566.

Sombatsompop, N., Markpin, T., \& Premkamolnetr, N. (2004). A modified method for calculating the Impact Factors of journals in ISI Journal Citation Reports: Polymer Science Category in 1997-2001. Scientometrics, 60(2), 217-235.

Subochev, A., Aleskerov, F., \& Pislyakov, V. (2018). Ranking journals using social choice theory methods: A novel approach in bibliometrics. Journal of Informetrics, 12(2), 416-429.

Thomä, J., \& Bizer, K. (2013). To protect or not to protect? Modes of appropriability in the small enterprise sector. Research Policy, 42(1), 35-49. 
Venturini, F. (2015). The modern drivers of productivity. Research Policy, 44(2), 357-369.

Verma, I. M. (2015). Impact, not impact factor.

Visnjic, I., Wiengarten, F., \& Neely, A. (2016). Only the brave: Product innovation, service business model innovation, and their impact on performance. Journal of Product Innovation Management, 33(1), 36-52.

Vučković-Dekić, L. (2014). Kako se piše naučno/stručni rad. Биомедицинска истраживать, 5(1).

Walsh, J. P., Lee, Y. N., \& Nagaoka, S. (2016). Openness and innovation in the US: Collaboration form, idea generation and implementation. Research Policy, 45(8), 1660-1671.

Walter, S. G., \& Block, J. H. (2016). Outcomes of entrepreneurship education: An institutional perspective. Journal of Business Venturing, 31(2), 216-233.

Walter, S. G., Parboteeah, K. P., \& Walter, A. (2013). University Departments and Self-Employment Intentions of Business Students: A Cross-Level Analysis. Entrepreneurship Theory and Practice, 37(2), 175-200.

Werfel, S. H., \& Jaffe, A. B. (2013). Induced innovation and technology trajectory: Evidence from smoking cessation products. Research Policy, 42(1), 15-22.

Wilson, N., Wright, M., \& Scholes, L. (2013). Family business survival and the role of boards. Entrepreneurship Theory and Practice, 37(6), 1369-1389.

Wohlrabe, K. (2016). Taking the temperature: A meta-ranking of economics journals.

Xu, N., Chen, Y., Fung, A., \& Chan, K. C. (2018). Contributing forces in entrepreneurship research: A global citation analysis. Journal of Small Business Management, 56(1), 179-201.

Zahra, S. A. (2015). Corporate entrepreneurship as knowledge creation and conversion: The role of entrepreneurial hubs. Small Business Economics, 44(4), 727-735.

Zhang, S. X., \& Cueto, J. (2017). The study of bias in entrepreneurship. Entrepreneurship Theory and Practice, 41(3), 419-454. 


\section{ŠTA MOŽEMO OČEKIVATI U BUDUĆNOSTI AKADEMSKOG ISTRAŽIVANJA? NAJČEŠĆI ISTRAŽIVAČKI PROBLEMI ANALIZIRANI U OKVIRU NAJISTAKNUTIJIH ČASOPISA IZ OBLASTI PREDUZETNIŠTVA}

\section{Rezime:}

U modernoj eri akademskog istraživanja, izuzetno je teško definisati celokupno ili nedovoljno ispitan istraživački problem. Svaki istraživač se u svom istraživačkom radu suočava sa ovim pitanjem. Potrebno je mnogo rada i truda da bi se pronašla tema koja je relevantna i koja će biti privlačna za izučavanje i istraživanje. $U$ središtu ovog rada su istraživački problemi iz oblasti preduzetništva. Rad se bavi istraživačkim problemima koji su se najčešće javljali u oblasti preduzetništva tokom proteklih pet godina. Sprovedena je anketa, sa ciljem da se identifikuju najmanje ispitane oblasti preduzetništva, kako bi se mogle predvideti buduće teme za istraživanje. Metode koje su se primenjivale, da bi se ovaj akademski cilj postigao, uključuju: opis, klasifikaciju i objašnjenje. Analizom uzorka, koji obuhvata 393 rada iz pet najuticajnijih časopisa koji se bave temom preduzetništva, autor je došao do zaključka da se, tokom proteklih pet godina, većina radova prvenstveno bavila inovacijama i naprednom tehnologijom, te da se jedva dotakla teme ženskog preduzetništva. Ovaj rad bi trebalo da pomogne budućim istraživačima da odaberu teme ili oblasti istraživanja u domenu preduzetništva.
Ključne reči:

preduzetništvo, referentni časopisi, citati 